\title{
DISKRIMINASI GENDER DI MEDIA TELEVISI
}

\author{
Nursalim \\ Fakultas Tarbiyah dan Keguruan UIN Suska Riau \\ nursalim@yaho.com
}

\begin{abstract}
This article studies how woman presented to society on television. In relation to masculine and feminine, television always descripts woman as a domestic person which depend on the power of men. Vice versa, a man is a public person who does not depent on the power of woman. Also the senetron theme presents the relation of masculine and feminine where man always comes up as a person who has capability to protects the woman which considered as the person who does not has capability. Therefore, the changes to the various televison programms has to be done absolutely by various side which bother about the existence of gender justice in the public area.
\end{abstract}

Kata Kunci: televisi, gender, perempuan. laki-laki

\section{PENDAHULUAN}

Dalam penggunaan perkatan sehari-hari, gender dan seks sering dimaknai oleh sebahagian orang sebagai hal yang sama. Padahal, sesungguhnya keduanya adalah hal yang berbeda. Gender lebih mengacu pada identitas budaya yang rapat pada satu unsur tertentu. Sedangkan seks mengacu pada identitas secara biologis.

Identitas secara biologi mempunyai konsekuensi kepada kodrat manusia. Contohnya, orang disebut perempuan karena akan menanggung konsekuensi kodrat yang ada padanya. Seorang perempuan suka atau tidak suka harus menjalankan fungsi-fungsi seks yang tidak dijalankan oleh laki-laki, seperti melahirkan, menyusui, dan berbagai aktivitas keperempuanan yang bersifat melekat padanya. 
Perbedaan kodrat secara biologi sering membuat salah satu pihak diperlakukan tidak adil dalam ruang sosial. Perempuan dengan berbagai aspekaspek kodratnya selalu diposisikan dalam ruang privat atau domestik. Manakala laki-laki diposisikan dalam ruang publik.Perbedaan posisi semacam ini telah menyebabkan tumbuhnya nilai di masyarakat bahwa kodrat yang berperan dalam ruang awam (public sphere) statusnya adalah sebagai warga negara kelas satu, manakala yang berperanan dalam ruang privat (domestic) berstatus warga negara kelas dua.

Pengidentifikasian semacam ini sesungguhnya adalah praktek dari ketidakadilan gender, seolah-olah perempuan yang mengurus rumah tangga dan dianggap tidak mampu mengurusi persoalan-persoalan di ruang publik yang menyangkut keperluan hidup orang banyak. Dan bukan tidak mungkin perempuan pun mempunyai kemampuan untuk mengaktualisasikan dirinya di ruang publik sebagaimana halnya laki-laki.

Persoalannya kemudian, adalah wacana publik dan berbagai otoritas kuasa yang mampu mengkontruksi nilai-nilai sosial hampir seluruhnya dikuasai oleh laki-laki, sehingga nilai yang kemudian berkembang di masyarakat dan hampir menjadi "kebenaran sosial" adalah nilai yang cenderung bias laki-laki.

Selama ini media khususnya televisi menawarkan kepada kita gambaran gender secara tradisional dan tidak rasional. Media menggambarkan stereotaip gender bahwa laki-laki adalah aggressive, independent dan violent. Manakala perempuan digambarkan sebagai seorang yang seksi, dependent dan domestik. Pada waktu yang sama pun media menyodorkan kepada kita gambarangambaran gender sebagai bagian dari stereotaip tradisional. Laki-laki digambarkan sebagai seorang yang sensitif dan pelindung, sedangkan perempuan sebagai seorang yang asservative dan independent ${ }^{1}$.

Media seperti televisi, majalah, surat kabar, internet dan lain-lain, sedikit banyaknya telah mempengaruhi cara hidup kita, pola dan perspektif kita. Apalagi televisi yang menjadi konsumsi hiburan masyarakat sehari baik itu pada masyarakat umum maupun masyarakat intelek. Dapat dipastikan bahwa masyarakat setiap hari selalu menikmati program-program yang ditampilkan dalam televisi. Sebagaimana dalam jurnal "Women's Studies Forum" (2001) Baudrillard menyatakan bahwa televisi adalah dunia, dimana banyak orang yang telah dipengaruhinya. Televisi banyak memberikan persepsi kepada masyarakat dengan hal-hal yang realitas. Meskipun pada kenyataannya, televisi tidaklah selalu menampilkan hal-hal yang nyata tapi komponen-komponen yang artificial (palsu) yang telah dibuat oleh orang yang berkuasa atau orang yang memproduksi televisi tersebut. Televisi mempunyai dampak yang sangat kuat dalam membentuk persepsi pemirsa tentang sex, gender dan juga identitas gender mereka. Televisi menyuguhkan diskriminasi gender melalui objektifitas masyarakat kerana masyarakat awam sering menjadi konsumen atas suatu produk televisi. Televisi seolah-olah menampilkan informasi yang valid tentang kebenaran hidup dan lain-lain. Hal ini karena televisi telah dibina dalam suatu masyarakat dan budaya yang dihasilkan melalui mekanisme sistem siaran². 
Persoalannya disini adalah bagaimana perempuan itu ditampilkan kepada masyarakat kita melalui televisi? Media, khususnya televisi, seharusnya mewakili keterlibatan perempuan melalui program-program yang ditampilkan. Bagaimana pun masalah-masalah ini selalu dianggap sebagai suatu hal yang biasa dari sebuah bentuk diskriminasi gender dan tidak perlu dijelaskan apalagi dijelaskan kepada masyarakat.

Slogan "For the society men and women work on an equal basis" mengindikasikan adanya diskriminasi perempuan dalam masyarakat. Masalah diskriminasi perempuan ini adalah masalah yang serius yang banyak kita jumpai di tempat kerja dan juga dalam kehidupan bermasyarakat lainnya yang di dalamnya ada laki-laki dan perempuan secara bersama-sama. Inilah yang menjadi alasan bahwa solusi dari semua ini bergantung bagaimana mengatasi masalah perbedaan gender karena perbedaan gender menghasilkan pembagian seksual dan sistem gender dalam masyarakat. Oleh itu, keterwakilan perempuan di televisi telah memberikan dorongan dan juga memberikan kontribusi atau sumbangan untuk dipertahankan dalam sistem tersebut. Keterlibatan perempuan menekankan ideologi perempuan dan memberikan kontribusi dalam pertumbuhan diskriminasi gender.

\section{PEMBAHA SAN}

\section{Gambaran Laki-laki dan Perempuan dalam Media Televisi}

Iskra Panevska menyatakan bahwa status sosial perempuan ditentukan oleh jumlah perempuan yang sebagian besar berada pada sektor awam (public sector) dan situasi dimana mereka bekerja. Secara objektif bahwa persamaan perempuan itu mungkin boleh dilihat dari berapa jumlah perempuan yang aktif dalam sektor publik dan mendapatkan posisi dalam ruang publik tersebut. ${ }^{3}$

Tema-tema perempuan dalam media antara lain adalah; a) Perempuan berada pada posisi yang minority dan underrepresented; b) Perempuan dan lakilaki ditampilkan dengan cara-cara yang stereotaip untuk pengekalan dan peneguhan terhadap pandangan-pandangan gender ; c) Tampilan hubungan antara laki-laki dan perempuan lebih menekankan pada peranan-peranan gender tradisional dan ketidakadilan kekuatan antara laki-laki dan perempuan.

Di sisi lain, media sering menampilkan laki-laki sebagai orang yang aktif, berpetualang, kuat, agresif (sexual) dan tidak banyak melibatkan diri dengan orang lain. Sedangkan perempuan selalu ditampilkan sebagai budak-budak (childish), lemah, cantik, kurus, pasif, ketergantungan dan tidak mempunyai keahlian. ${ }^{4}$

Kebanyakan laki-laki yang ditampilkan dalam televisi adalah independent (tidak bergantung), agresif dan kuat. Semua program-program televisi menampilkan laki-laki sebagai orang yang serius, confidence (percaya diri), cakap dan mempunyai kuasa. Contohnya dalam film Fight Club, Armageddon, Gladiator, dan lain sebagainya yang menggambarkan maskulin laki-laki, yaitu hard, taough, independent, aggressive (sexuality), unfraid, violent, totally in control of emotion (dapat mengkawal emosi) dan tentunya tidak feminine ${ }^{5}$. Laki-laki juga dominan dalam 
majalah terkenal. Jackson Katz menyatakan bahwa media mengajarkan laki-laki untuk menjadi "real man" yang mempunyai kekuatan dan mampu mengkawal.

Kadang-kadang media mengekspos perempuan pada peranan-peranan yang tidak tradisional atau ditampilkan dengan kualitas yang tidak biasa. Banyak media menampilkan budaya-budaya yang dibina dalam masa yang lama dengan stereotaip perempuan dan feminin. Perempuan yang ideal adalah muda, kurus dan selalu terlibat dengan laki-laki dan anak-anak, menarik dalam berhubungan atau bekerjasama dan juga yang berkaitan dengan kerja-kerja rumah tangga. Pandangan tradisional tentang feminin bahkan tampak pada acara-acara bahwa perempuan harus tampak muda, seksi, atraktif, dan menjadi pendamping laki-laki6.

Dalam kaitannya dengan feminin-maskulin, media sering menggambarkan perempuan sebagai seorang yang berada dalam ruangan domestik yang bergantung pada kekuatan dan kekuasaan laki-laki. Manakala laki-laki adalah sebaliknya, yaitu, sentiasa berada dalam ruangan awam dan tidak bergantung pada kekuasaan perempuan. Begitu juga dengan tema-tema media yang juga menampilkan hubungan feminin-maskulin dimana laki-laki selalu tampil sebagai seorang yang mempunyai kemampuan yang dapat menjaga perempuan yang dianggap sebagai seorang yang tidak mempunyai kemampuan.

Televisi sebagai media komunikasi massa merupakan media yang strategis dalam mensosialisasikan nilai-nilai dan ide (gagasan). Televisipun mempunyai pengaruh dalam pembentukan karakter individu dan mampu mendorong individu untuk meyakini suatu standard kebenaran. "Kebenaran" yang disosialisasikan televisi dapat menjadi dasar referensi penonton. Masalah bias perempuan di publikpun akan semakin kuat, baik televisi menyadari atau tidak bahwa ia ikut mensosialisasikan ide dan nilai-nilai yang mengandung bias gender tersebut. Jika para pemilik dan jurnalis televisi tidak memiliki sensitifitas terhadap berbagai persoalan ketidakadilan gender, maka televisi mempunyai peran dalam menumbuhkembangkan praktek ketidakadilan gender di tengahtengah masyarakat.

Bias gender sentiasa hadir dalam sejumlah tayangan televisi. Dalam tayangan senetron bersiri 'Putri yang ditukar" kehidupan perempuan "digambarkan" hanya pada peranan-peranan domestik (rumah tangga) atau individu yang tidak lebih pintar dari laki-laki, yang posisinya hanya menjadi pelayan laki-laki, serta berbagai stereotaip yang mengarahkan bahwa perempuan adalah kodrat yang tidak qualified untuk masuk dalam ruangan awam (public sphere).

Senetron-senetron yang ada jarang menampilkan perempuan sebagai sosok (profile) pengambil keputusan dalam berbagai kebijakan publik, perempuan masih dianggap sebagai peran pembantu dalam kehidupan awam. Misalnya, dalam sebuah sinetron seorang perempuan sering ditampilkan sebagai sekretaris dan jarang ditampilkan sebagai direktur/bos atau pemimpin sebuah lembaga awam. 
Bias perempuan lainnya yang dapat disaksikan di layar televisi adalah acara-acara pertandingan kecantikan (seperti, miss universe, ratu kecantikan, dan lain sebagainya) yang menampilkan perempuan sebagai peserta pertandingan. Pertandingan yang diadakan biasanya hanya menekankan penilaian pada keindahan tubuh perempuan yang dapat membangkitkan libido laki-laki dibandingkan dengan upaya mengeksplorasi kecerdasan yang ada dalam diri perempuan peserta pertandingan. Acara yang ada tersebut lebih pada upaya memuaskan hasrat/nafsu kelaki-lakian (spirit of patriarchal).

Kenyataan-kenyataan sebagaimana yang ditampilkan di televisi terkesan lebih memihak kepada kaum laki-laki, karena sebagian besar televisi masih didominasi (dikuasai) oleh para laki-laki, baik dalam hal penguasaan aset permodalan ataupun para pekerja tehniknya. Oleh karena itu, cadangan terhadap berbagai acara televisi mutlak dilakukan oleh berbagai pihak yang peduli akan adanya keadilan gender di ruang publik.

Prio SM, jurnalis televisi, membahas bagaimana pemberitaan tentang perempuan yang dipandang lebih sensasional dibanding fakta yang melibatkan laki-laki. Pada aspek informasi hiburan, Veven Sp Wardhana dalam buku Eksplorasi Gender di Ranah Jurnalisme dan Hiburan memaparkan tentang posisi perempuan di dunia hiburan seperti drama atau film televisi. Perempuan digambarkan sebagai makhluk yang pasrah, lemah, pemaaf, perayu, jahat, atau masih banyak sifat lainnya yang tercermin dalam drama kita saat ini. Dan jika dilihat dari aspek iklan, dunia periklanan ternyata merupakan lahan yang banyak diminati oleh perempuan. Tetapi, apakah perempuan mempunyai bargaining posisi dalam menerima peranan yang ditawarkan dalam iklan? Atau apakah keinginan perempuan yang hanya mencari nama dan uang sering menjadi alasan bahwa perempuan sering terlihat dilecehkan dan diremehkan dalam iklan.

\section{Gender dan Produksi Televisi}

Televisi masih menyambung tradisi gender dengan sterotaip karena ia memantulkan dominasi nilai sosial. Selain itu, televisi juga menayangkan sebagai "inatural". Dalam masyarakat yang masih dikuasai oleh laki-laki, produksi televisi juga dikuasai oleh laki-laki dan dipengaruhi dengan streotaip.Secara tidak langsung ia menguatkan lagi bayangan tradisi maskulin yang berkelajutan dengan streotaip perempuan. Banyak cerita dalam televisi dibuat supaya diintepretasi dari perspektif maskulin. Penonton selalunya diajak supaya mengenal sifat laki-laki dan menerima sifat perempuan? ${ }^{7}$.

Perempuan banyak belajar daripada televisi bahwa ini adalah dunia lakilaki dan belajar untuk memaparkan pandangan mereka sendiri. Sekarang ini sudah mulai terjadi perimbangan jumlah perempuan yang membaca berita. Dulu kebanyakan pembaca berita terdiri atas laki-laki dan telah menunjukkan bahwa perempuan kurang diberi perhatian secara serius. Walau penonton mengatakan bahwa daya tarik perempuan lebih memainkan peranan penting dalam pemilihan mereka dibandingkan laki-laki, tetapi Ada juga bukti yang 
menyatakan bahwa pembaca berita laki-laki lebih diyakini kebenarannya dibandingkan pembaca berita perempuan ${ }^{8}$.

\section{Jumlah Laki-Laki dan Perempuan di Televisi}

Walaupun masih terbatas untuk penyelidikan televisi, analisa menunjukkan bahwa ada perbedaan jumlah laki dan perempuan di televisi. Jumlah perempuan di televisi lebih kecil dibandingkan dengan jumlah laki-laki. Dalam drama televisi umum, jumlah laki-laki melebihi jumlah perempuan dengan perbandingan 1 banding 3 atau 4 . 70\% hingga 80\% dari tokoh kartun anak-anak ialah laki-laki. Dalam kartun anak-anak perbandinagn jumlah laki-laki dengan perempuan, 1 banding 10. Dalam opera sekalipun perempuan 3 banding $7^{9}$. Demikian juga tokoh utama laki-laki yang lebih banyak dibandingkan tokoh utama perempuan. Dalam dunia nyata jumlah perempuan lebih banyak dari jumlah laki-laki. Dalam konteks ini, televisi tidak mengambarkan keadaan demografis yang sebenarnya.

\section{Perempuan versus Seks}

Kebanyakkan penelitian sosial membedakan gender dengan sex. Peranan gender tidak sebatas dipahami secara biologis tetapi dapat dibedakan mengikuti kebudayaan dan perkembangan zaman. Menurut penelitian sosial peranan gender ini dibentuk melalui budaya sosial.

Dalam sesuatu kebudayaan kelaki-lakian dan kerempuanan mungkin didefinisikan secara berbeda menurut etnis, kelas sosial, usia dan kondratnya. Dalam hubungan ini tidak lagi disebut kelaki-lakian dan keperempuanan tetapi lebih tepat lagi disebut golongan laki-laki dan perempuan. Laki-laki digambarkan sebagai pemimpin garang, tegas, bebas dan berani menghadapi risiko. Perempuan digambarkan sebagai makhluk yang penyayang, sopan, simpatik, ketergantungan, emosional. Kualitas seperti itu berbeda-beda berdasarkan anggapan manusianya.

Semua laki-laki dan perempuan menyadari kelaziman budaya dalam stereotaip gender tradisional. Televisi memberikan kesadaran tentang hal ini. Peranan seks melibatkan budaya seperti laki-laki yang suka mencari pencapaian dan penguasaan. Perempuan bersifat menerima dan menunggu. Hubungan seperti ini selalu menyeabkan ketegangan dan kekurangharmonisan. ${ }^{10}$

\section{Perempuan dan Pekerjaan}

Kebanyakan perempuan di televisi digambarkan sebagai makhluk yang tunduk pada beberapa peranan. Peranan laki-laki adalah jauh lebih besar dan lebih menarik. Perempuan dalam televisi digambarkan dalam bentuk tradisional seperti istri, penjaga rumah, staf dan perawat yang selalu melayani orang yang sakit. Laki-laki digambarkan sebagai suami, bapak dan juga sebagai ahli olahraga, orang ternama, wiraswasta. Status perkawinan selalu mengambarkan keadaan perempuan dibandingkan laki-laki. Laki-laki di televisi selalu dipaparkan dalam pekerjaan yang mempunyai status tinggi dan jarang di rumah. 
Perempuan digambarkan sebagai pelengkap dalam kehidupan mereka sendiri. Perempuan sebagai bunga-bunga di tempat kerja sehingga ada kebiasaan perempuan harus sekian persen dari laki-laki untuk menjadi suana kerja lebih hidup.

Pengambaran perempuan dan laki-laki yang demikian adalah tradisional dan stereotaip. Fenomena ini cukup sesuai untuk kelansungan peranan gender. Ini berlaku dengan ciri-ciri keperempuanan yang bergabung seperti emosi, cermat, kerjasama, perasaan dan patuh. Ciri-ciri kelaki-lakian cenderung bergabung dengan sifat-sifat seperti rasional, efisien, mandiri dan kuat.

Media televisi selalu menggambarkan perempuan 'baik' adalah perempuan yang patuh, sensitif, dan mengurus rumahtangga. Perempuan 'jahat' adalah bersifat memberontak, bebas dan mementingkan diri sendiri. Perempuan 'idaman' yang stereotaip ialah bersopan santun, pendiam, sensitif, patuh, tidak bersaing dan manis sesuai kodratnya. Laki-laki cenderung menjadi kuat secara fisik, ganas, pendesak, bebas, memiliki inisiatif dan bercita-cita tinggi. Dalam televisi dan film tergambarkan mewakili kebaikan, kuasa, yakin, pelindung, ahli dan berhasil. Mereka dibentuk seperti itu untuk berhasil dalam sistem ekonomi dan berdaya saing.

Dalam beberapa film digambarkan laki-laki cenderung untuk dijadikan lebih dominan, lebih ganas, dan lebih berkuasa daripada perempuan. Laki-laki di televisi adalah lebih merendah perempuan dan sebaliknya. Mereka mengatur, merokok dan minum, olahragawan, dan mampu membuat rencana yang matang. Perempuan di televisi lebih cenderung menjadi orang masih singel/gadis dari pada gambaran laki-laki yang sudah berkeluarga. Perempuan digambarkan dibawah 30 tahunan dan berpasangan dengan laki-laki yang mungkin sudah jauh lebih tua umurnya. Jadi, imej dalam televisi sering menonjolkan pengertian penguasaan laki-laki terhadap perempuan.

\section{Iklan}

Bila dilihat iklan di televisi, stereotip gender cenderung menjadi semakin kuat. Dalam iklan, laki-laki cenderung dipaparkan sebagai insan yang lebih bebas. Mereka digambarkan lebih banyak bekerja dibanding perempuan. Gambaran peranan perempuan dalam iklan adalah sebagai ibu rumah tangga dan pengasuh anak-anak di rumah. Laki-laki dipaparkan dalam iklan mobil atau barang-barang wira usaha, perempuan mengiklankan alat-alat rumah tangga, Laki-laki ditonjolkan dengan latarbelakang pekerjaan di luar rumah, sedangkan perempuan dilatarbelakangi pekerjaan dalam rumah. Laki-laki selalu memperagakan sebagai orang yang berkuasa, dan semakin tua akan memperoleh kekuasaan yang tinggi. Pada perempuan digambarkan sebagai peran kedua mendampingi pekerjaan laki-laki, dan makin tua perempuan makin hilang dari wilayah pekerjaan.

\section{Iklan dan Program untuk Anak-Anak}


Iklan televisi modern selalu mengutamakan laki-laki dan perempuan, tetapi laki-laki cenderung lebih dominan. Iklan memberi gambaran bahwa lakilaki sering terlibat dalam berbagai aktifitas. Laki-laki lebih agresif dari perempuan. Laki-laki biasanya ditunjukkan sebagai seorang yang aktif, agresif, rasional dan penuh persaingan. Iklan anak laki-laki mengambarkan keaktifan dalam berbagai adegan. Iklan anak perempuan lebih cenderung mempunyai keayuan, menurut perasaan dan latat musik yang lembut.

Hampir 85\% watak anak-anak di televisi ialah laki-laki walaupun dalam bentuk kartun atau bentuk cerita binatang. Begitu juga dengan jenis pekerjaan anak laki-laki lebih bervariasi dari pada anak perempuan yang bekerja pada bidang tertentu saja.

Pada umumnya di televisi anak laki-laki lebih cenderung ditunjukkan sebagai aktif, agresif, rasional dan penuh persaingan. Mereka lebih melibatkan diri dalam aktivitas yang dianggap milik laki-laki seperti olahraga, kemping dan kegiatan lainnya. Perempuan lebih ditunjukkan dengan berbicara di telepon, membaca, membantu pekerjaan rumaqh tangga. Jenis ini juga dijumpai di program pendidikan untuk anak-anak.

\section{SIMPULAN}

Media sangat berperan sebagai agen utama sosialisme. Selain keluarga dan teman sebaya, media banyak membantu dalam membentuk peranan gender. Belajar untuk menjadi perempuan dan laki-laki tetapi ini tidak dalam bentuk serta merta. Media juga berperan untuk membentuk watak-watak manusia. Tidak dapat dipungkiri bahwa televisi merupakan penarik imej gender yang kuat. Ini jelas dapat dilihat apabila sebagian remaja laki-laki menjadikan hero laki-laki sebagai 'role model' dan bukan ayah atau bapak mereka sendiri.

Perempuan dalam media selalu menjadi pemanis, pelembut, bahkan perempuan menjadi daya tarik tersendiri mengisi acara-acara atau siaran-siaran di media. Daya tarik yang dimaksud kadang-kadang melecehkan perempuan sendiri karena didalamnya mengambarkan bahwa perempuan adalah makhluk yang lemah yang harus dilindungi, disayangi, kecantikkanya untuk ditonton dan dinikmati oleh semua orang.

Laki-laki selalu digambarkan sebagai makhluk yang kuat, energik, pelindung, dan tidak terkuasai oleh perempuan. Pengambaran laki-laki dalam media menunjukkan bahwa laki-laki ridak terlalu membutuhkan perempuan untuk berpikir atau orang yang dapat dihandalkan, tetapi digambarkan bahwa laki-laki membutuhkan perempuan sebagai teman atau pemanis pada suatu even atau acara.

Tampak dari penggambaran di atas, bahwa perempuan adalah makhluk yang belum sepenuhnya berdiri sendiri, tetapi masih membutuhkan laki-laki untuk melindungi diri. Pandangan ini tidak akan berubah jika media dan masyarakat pada umumnya tidak berusaha untuk mengubahnya. Padahal manusia itu pada hakikatnya sama dan tergantung pada diri untuk mencari persamaan tersebut. 


\section{Endnotes:}

1 Ibrahim, Idi Subandy (Editor). 1998. Perempuan dan Media; Konstruksi Ideologi Gender dalam Ruang Publik Orde Baru. Bandung: Rosda Karya

2 Ibid

3 Tavris, Carol. 1992. Mismeasure of Woman. New York: Touchstone.

4 Op. Cit. hlm. 160

5 Siregar, Ashadi, dkk (penyunting). 2000. Eksplorasi gender di Ranah Jurnalisme dan Hiburan. Yogjakarta: LP3Y

6 Op. Cit. hlm. 160

7 Gender dalam Ruang Publik Orde Baru. Bandung: Rosda Karya

8 T. Wood, Julia. Gendered Lives; Communication, Gender and Culture. Sixth Edition. Thompson Wadsworth

9 Mosse, Julia Cleves. 1993. Half the World, Half a Chance; an Introduction to Gender and Development. Oxford: Oxfam.

10 Lips, Hillary M. Sex E Gender an: Introduction. California, London

\section{DAFTAR PUSTAKA}

Gender dalam Ruang Publik Orde Baru. Bandung: Rosda Karya

Ibrahim, Idi Subandy (Editor). 1998. Perempuan dan Media; Konstruksi Ideologi Gender dalam Ruang Publik Orde Baru. Bandung: Rosda Karya

Lips, Hillary M. Sex E Gender an: Introduction. California, London

Mosse, Julia Cleves. 1993. Half the World, Half a Chance; an Introduction to Gender and Development. Oxford: Oxfam.

Siregar, Ashadi, dkk (penyunting). 2000. Eksplorasi gender di Ranah Jurnalisme dan Hiburan. Yogjakarta: LP3Y

T. Wood, Julia. Gendered Lives; Communication, Gender and Culture. Sixth Edition. Thompson Wadsworth

Tavris, Carol. 1992. Mismeasure of Woman. New York: Touchstone. 